\title{
Transportation and subsoil use: integration for the Arctic economic development in Russia
}

\author{
Anatoliy Sleptsov ${ }^{1}$, Violetta Gassiy ${ }^{2, *}$, Jean-Pierre Desideri ${ }^{3}$ and Afanasiy Postnikov ${ }^{2}$ \\ ${ }^{1}$ North-Eastern Federal University, 58 Belinsky str., Yakutsk, 677000 Russia \\ ${ }^{2}$ Kuban State University, 149 Stavropolskaya st., Krasnodar 350040 Russia \\ ${ }^{3}$ University of Versailles Saint-Quentin-en-Yvelines (UVSQ), Bâtiment Buffon, 55 Avenue de Paris, 78000, \\ Versailles, France
}

\begin{abstract}
The issues of the Russian Arctic development are considered in the paper. The authors study the trends and factors in the formation of the Arctic transportation. The subsoil use is researched as an industry that stimulates the active development of the Arctic at the present stage. The analysis of the interdependence of the two sectors of the economy is carried out as well as the reasons for their integration are substantiated. The authors consider government incentives for investment in the Arctic. The article discusses the reasons why it is still not possible to use the resource potential of the Arctic to its full capacity. According to the authors, the transport infrastructure does not meet the needs of investment. They suppose that an obstacle to the further inclusion of the Russian Arctic in an active economic turnover is the delay in the construction of the infrastructure to support the Northern Sea Route: ports, icebreakers and rescue vessels. A breakthrough in transportation is required for further successful implementation of investment projects for the extraction of hydrocarbons and other minerals. Therefore, the development of the Arctic should be considered only in the context of the integration of subsoil use and transportation. In conclusion, the authors outline the main tasks that the state needs to solve for the Arctic policy implementation.
\end{abstract}

\section{Introduction}

In last decade, the vector of state policy in Russia has headed towards the Arctic. The government's attention to this important region is explained by the need to ensure the national security and economic interests of the country. Climate change is transforming the usual attitude towards the Arctic, expanding the potential for the development of the Arctic territories, including logistics and mining. Melting ice and increasing the availability of natural resources on the continent stimulate technological progress, which leads to the development of innovative solutions in the field of subsoil use, storage, processing and transportation of raw materials and goods. An example of such rapid technological change is the production of liquefied natural gas (LNG). The technologies applied at the LNG fields, related not only directly to hydrocarbon production, but also to environmental protection, organization of communications, and labor safety, have actually led to an innovative shift in the mining industry. According to the Brookings Institution research, the LNG was named as a key priority in Russian energy sector in the future to gain the leadership in world oil market along with Saudi Arabia [1]. In the future, it is planned to expand the share of liquefied gas in the total volume of produced hydrocarbons. At the federal level, a decision was made to implement at least ten LNG projects in the future. By 2035, the government plans to increase LNG production at least threefold. According to Rosstat in 2020 the production of LNG in Russia has increased by $3.5 \%$, to 30.5 million tons [2]. The environmental friendliness of natural gas can be considered as a factor in the development of subsoil use in this direction. Since the EU countries have adopted a strategy of transition to zero consumption of hydrocarbons in 20-30 years, natural gas can be considered as a "transitional" type of fuel. The development of LNG and the need to create new capacities for its transportation is a separate example of significant shifts in the subsoil use industry. Thus, the transformation of the industrial sector for the extraction of natural resources means improved transportation, including modes of transport and logistics. In the article, the authors investigate the relationship between the transport industry and subsoil use, identify the problems of their development in the Arctic, and offer recommendations for their solution.

\section{Materials and Methods}

The research methodology includes the use of a wide range of data collection and analysis. Among the main

* Corresponding author: vgassiy@mail.ru 
methods used in the article, the authors applied the following:

- method of retrospective and legal analysis;

- data analysis and assessment;

- deduction method to identify causal relationships.

In addition, during the research the system, essential and institutional approaches were used. In this study, the Arctic is considered as a global ecological and economic space, which is part of the world economic system. The Arctic space is permeated with institutional subsystems, and their elements function under the influence of local political, economic, social and environmental factors. For this reason, it is important to study the Russian Arctic as a part and its contribution to the world geopolitical and economic space, as well as the role of this macro region in the country's economy and social sphere.

The institutional approach assumes that a legal environment has been formed in the Russian Arctic, which determines the norms and foundations of regulation and the functioning of its subjects. These entities carry out social ties, have associations and conduct economic activities in the Arctic. The main subjects of the Russian Arctic include the following:

- government (federal, regional, local);

- population, represented both directly and through the system of non-profit organizations;

- business of any kind (multinational companies, medium and small businesses).

It should be noted that the specificity of the Arctic region is the diversification of the population by the nature of activities, lifestyle. Moreover, residents of urban and rural areas of the Arctic have a big difference in living standards. Arctic cities are more concentrated on the production and extraction of any natural resource (Norilsk, Vorkuta), the functioning of the port (Murmansk). The economies of such cities have been transformed by monopolies. In fact, the development of the territory directly depends on the success and profitability of the city-forming enterprise. The rural area of the Arctic is characterized by the problems of poverty, unemployment, orientation towards traditional types of farming. These are indigenous peoples who play a significant role in the ethno-cultural life of the Arctic and form the historical heritage of northern culture. They conduct traditional nature management, are engaged in reindeer husbandry, fishing, picking berries, mushrooms, medicinal herbs and other plants. Therefore, the management of the Arctic macro regions in Russia is due to the complexity: the need to take into account national interests and external influences with the need for social transformations without damage to the environment.

The complexity of management as well as modern trends has required a revision and update of the basic documents for the implementation of state policy in the Arctic. The Russian Arctic strategy was adopted in 2020 [3]. It outlines the importance of the Arctic for the realization of the national interests of the Russian Federation. The Arctic is a treasure trove of minerals. According to experts, about $80 \%$ of natural gas reserves are concentrated in the Arctic territories. The uneven development of the Arctic regions, their remoteness from industrialized centers and the need to transport raw materials are among the main factors in the transformation of state policy in the Arctic. An important aspect is the expansion of the capabilities of the Northern Sea Route as an international corridor for the transportation of products between Europe and Asia. In the last decade, non-Arctic countries such as South Korea, Japan and China have become more active in the Arctic. They have achieved observer status in a number of important Arctic international organizations, primarily in the Arctic Council. The reason for this attention to the Arctic is easy to explain. For many years there has been a discussion about the options for trans-Arctic shipping: the Northeast Passage between the Atlantic and the Pacific north of Russia, the Northwest Passage through Canada's Arctic Archipelago, and the Central Route across the North Pole [4]. For the largest Asian carriers, the NSR is the most attractive today. Moreover, we believe that Arctic shipments from Asia to Europe are the most sensitive area in the implementation of the political interests and economic policies of Asian countries. Therefore, such attention is paid to the problems of the NSR development.

Undoubtedly, the NSR is a tool for expanding Russia's presence in the Arctic and internationally as an important operator of the world economy. The total volume of traffic by the Northern Sea Route is constantly increasing. In 2020 it amounted to almost 31 million tons. There was also an increase in the volume of cargo transportation in the Arctic by rail, Tab. 1:

Table 1. The costs of transportation, storage and delivery of goods by main-line freight rail transport, US\$ [5]

\begin{tabular}{lcccc}
\hline & 2016 & 2017 & 2018 & 2019 \\
\hline $\begin{array}{l}\text { Russian } \\
\text { Arctic }\end{array}$ & 74,2 & 42,2 & 45,8 & 73,9 \\
\hline $\begin{array}{l}\text { Russian } \\
\text { Federation }\end{array}$ & 2842 & 3304 & 4479 & 6209 \\
\hline
\end{tabular}

Russia's ambitious plans for the development of the Arctic and its resources require the solution of an important task. The transport infrastructure does not meet the goals of subsoil use and investment projects' implementation. In most of the territory, there is no port infrastructure, the necessary sites for light aircraft, which transports personnel, small cargo between fields and settlements. Also, an obstacle to further inclusion of the Russian Arctic in an active economic turnover is the delay in the construction of the infrastructure to support the Northern Sea Route: ports, icebreakers and rescue vessels.

It should be noted that the transportation framework of the Russian Arctic can be divided into two parts: western and eastern [6]. The western part is characterized by a greater degree of the development cause of located industrial facilities, railways, cities with a population of more than 100 thousand people (Murmansk, Arkhangelsk, Norilsk). Historically, the western part of the Russian Arctic is more developed. The eastern part 
includes hot spots for industrial development, is less socially developed. It has also extensive economy and a high dispersion of the population. For example, the Arctic Yakutia, being the largest region of Russia, has a population density of 0.04 people per $\mathrm{km}^{2}$.

To speed up the development of the Arctic territories, the government proposed to introduce a special economic regime. According to this approach, investors receive benefits for the implementation of innovative projects in the field of subsoil use, construction of engineering and transport infrastructure. Particularly interesting for investors is the instrument for providing a 15-year preferential tax regime for the projects of hydrocarbons production on the Arctic shelf. In recent years, a significant increase in the investment in the Russian Arctic is associated precisely with the implementation of subsoil use projects on the ocean shelf.

All economic entities in the Arctic can obtain resident status. It makes it possible to use tax incentives during the implementation of the investment project. To obtain the status of the Arctic zone resident, the investor must meet several conditions. For example, the volume of capital investments in a project should not exceed $25 \%$, and their minimum volume should not be less than 1 million rubles. Also, to support investors, the government offered financial instruments that were not previously used in the practice of developing the Arctic territories. We are talking about subsidizing coupon bonds issued for the modernization of production and the introduction of green technologies, as well as leasing of the equipment intended in the Arctic.

The data of the Russian Federal Statistics Service show the growth of innovations applied in the Arctic, fig. 1:

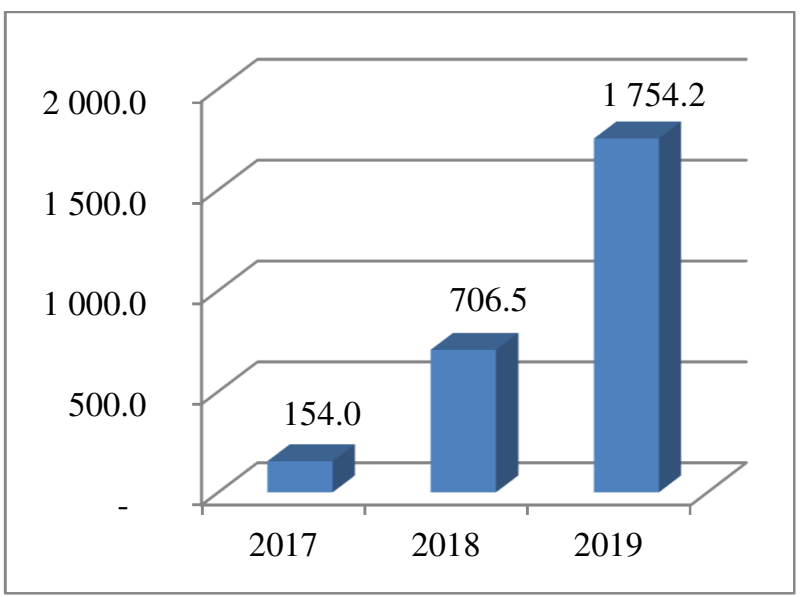

Fig.1. Volume of innovative goods and services in the Russian Arctic, \$US [5]

In recent years, business costs for innovation have increased significantly in the Arctic zone. These include, first of all, the costs of the business for the ecological innovation of production. Each year, environmental requirements for subsoil use in the Arctic are tightened. Therefore, the state considers the stimulation of green activity as a basis for subsidizing investors.

\section{Results}

In 2021 a transport strategy for the Arctic is currently being developed in Russia. It should provide a number of measures to expand the network of railway, sea and airport hubs. To finance high-cost projects for the Arctic infrastructure development, this strategy will use publicprivate partnerships. For the Russian Arctic practice, projects implemented on the basis of PPP are a novelty, although in other Arctic countries there are successful examples of the implementation of infrastructure projects based on this mechanism. For example, in Canada over the past 20 years, 98 projects have been implemented on the basis of public-private partnerships. The cost of all investment projects is estimated at $\$ 61$ billion. In 2017, the Iqaluit International Airport Improvement Project was implemented [7]. In 2013, the Government of Nunavut decided to modernize the airport in the capital Iqaluit. The land of Nunavut is characterized by the fact that the communities are located on the islands and on the mainland, and communication between them is maintained only by aviation. Therefore, the modernization of the airport was seen as an opportunity to improve the only way of transport links in the region. This project aims to improve the quality of life for Nunavut residents, businesses and tourists. Three actors took part in the project. Capital expenditures for the construction of the new airport are $\$ 288.5$ million of which the government of Nunavut contributed \$ 68.7 million, PPP Canada contributed \$ 72.8 million, and the Arctic Infrastructure Partners contributed the shortfall from its own and borrowed sources. The experts estimate the net present value (NPC) of the 30-year project agreement at \$ 418.9 million.

It is important to use in the Russian Arctic the experience of foreign countries in the implementation of projects for industrial development especially in transportation based on PPP [8]. The Arctic regions of Russia are experiencing a serious need for infrastructure projects, especially underdeveloped flight connections between remote settlements. Transport communication between them is irregular, and flights are carried out on the principle of the fullness of the aircraft cabin. At the end of 2020, the Ministry for the Development of the Far East and the Arctic decided to implement a new type of PPP for regional development - the Arctic concession. It will allow capitalizing tax revenues that the budgetary system will receive through the implementation of investment projects in the Arctic region.

The global trend towards more environmentally friendly fuels is reflected in the Arctic subsoil use. Oil production is gradually decreasing, while the implementation of investment projects for natural gas production is increasing, fig. 2: 


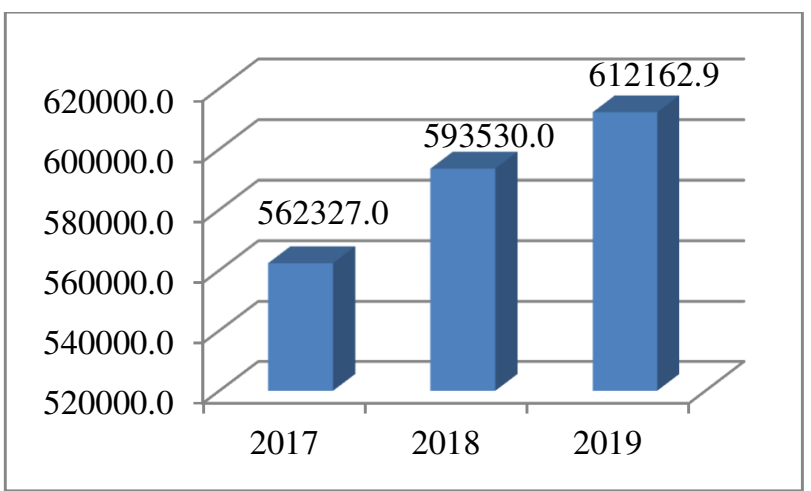

Fig.2. Natural gas extraction, mln tons [5]

Perhaps the decline in oil production in the Arctic zone is also associated with general global trends in the energy market. We are talking about the deals of the OPEC + countries to reduce the daily volumes of crude oil production. Since 2019, the price per barrel of oil has continued to fall actively. The 2020 pandemic has exacerbated this trend. The world economy entered a period of recession; the need for fuel has significantly decreased, as countries everywhere introduced restrictions on the movement of vehicles and citizens or even lockdowns. The tourism business has actually collapsed. The energy market is currently undergoing an ambiguous recovery phase, fig. 3 .

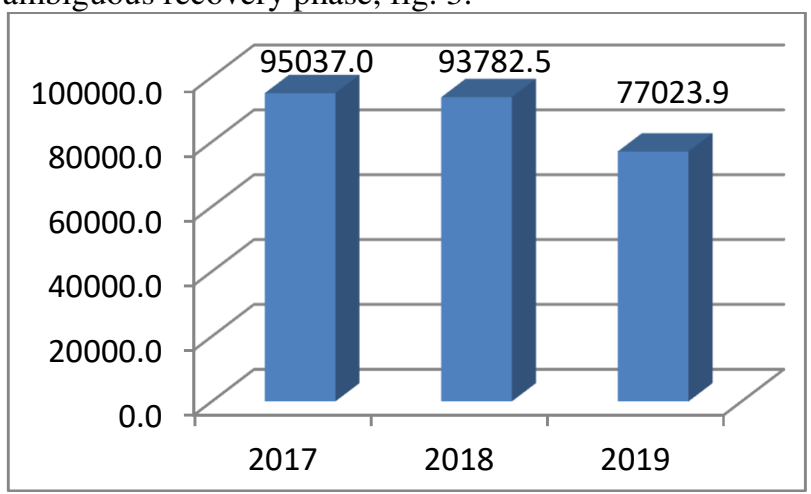

Fig.3. Oil extraction in the Russian Arctic, mln tons [5]

Investment Arctic projects are, first of all, the extraction of minerals, the volumes of which make this region a priority for economic development [9]. The subsoil of the Arctic territories of Russia contain reserves of hydrocarbons, non-ferrous and rare earth metals. According to official data, the Arctic has over 80 billion barrels of oil, one and a half trillion cubic meters of natural gas; about 800 billion tons of coal. These reserves are estimated at more than \$ 30 trillion. The reserves of non-ferrous and rare-earth metals are represented by platinum, copper-nickel ore, iron, phosphorus, gold and diamonds, niobium, etc.

Comparison of data on the extracted minerals in the Arctic zone and in the country as a whole shows that for Russia, subsoil use in the Arctic is of great importance. For example, Table 2 shows the volume of extraction of the main types of minerals, according to which from $30 \%$ to $100 \%$ depending on the type of raw material is mined in the Russian Arctic. Moreover, there are deposits of rare earth metals, whose deposits were discovered relatively recently, but they are also located in the Arctic territories.

Table 2. Mining in Russia

\begin{tabular}{ll} 
Types of the raw materials & 201 \\
& 9 \\
\hline
\end{tabular}

Bituminous and brown coal, million tons

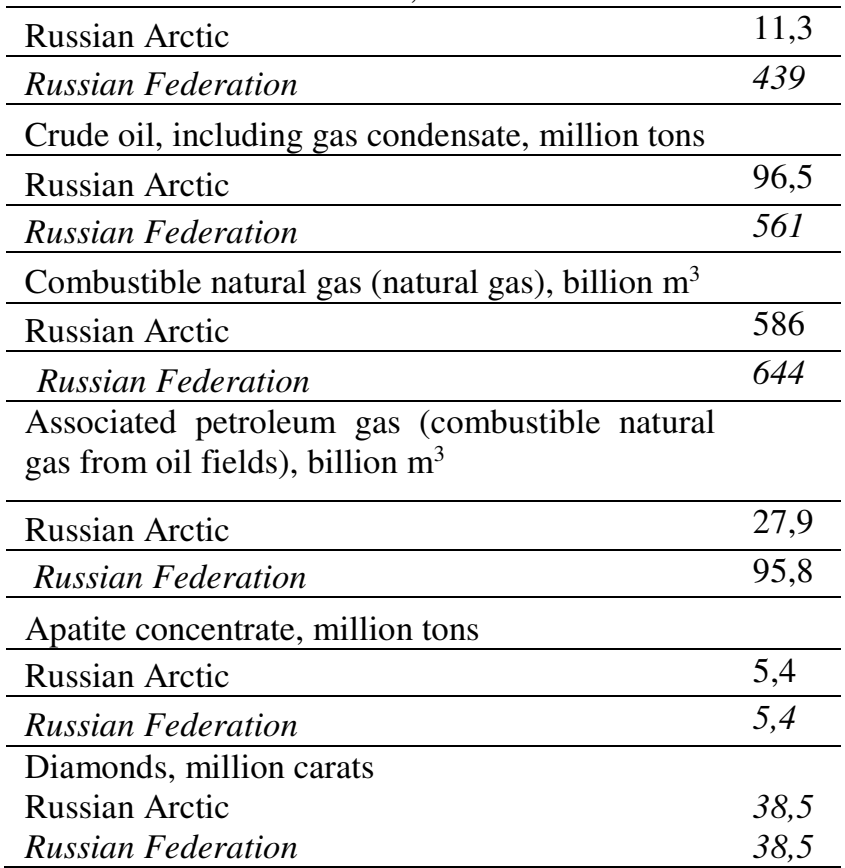

Effective development of the Arctic opens up new opportunities for financing government programs and implementing the social goals of the state. There is an acute shortage of modern social and engineering infrastructure in Russia. Arctic subsoil use is actually a chance to increase budget expenditures by developing economic approaches to using the potential of the energy sector [9]. This approach presupposes intensive construction of infrastructure for the extraction and transportation of minerals. As the data analysis of the Arctic subsoil use has shown, currently the greatest interest for Russia is the hydrocarbons production, which is export oriented. However, taking into account the existing risks, it is necessary to diversify the transport infrastructure and partners.

A number of political decisions taken by the Russian government, as well as the concluded agreements on the construction of trunk pipelines, indicate that states are striving to insure themselves against possible disruptions in the transportation and sale of raw materials.

\section{Conclusion}

What are the prospects for Russia to wake up the Arctic region? Still this "sleeping" region with its colossal economic potential hasn't been fully developing due to natural limitations (economic activity is not always possible all year round), as well as significant financial costs due to harsh climatic conditions and complex logistics. Of course, these factors need to be taken into account when developing Arctic policy. The Russian 
policy in the Arctic should be based, first of all, on the solution of the following tasks:

- Development of transportation and logistics corridors connecting industrial centers and transport hubs. This will give an impetus to territorial development, since the Arctic is characterized by a significant dispersion of the population, and settlements are actually cut off from each other. The construction of roads and other transport infrastructure for the purposes of the subsoil use industry will lead to the associated inclusion of existing settlements in a single Arctic transport framework.

- Reassessment of natural resources, which will provide updated data on the potentially available reserves of minerals. This applies not only to reserves of gas, oil and other popular resources. It is also necessary to refresh the data on the quality of the landscape, coastlines, geobotanical characteristics of the territory. For example, geobotanical studies of the Arctic regions of Yakutia were carried out in 1977-1978. Over 40 years there have been significant changes in the quality and composition of the vegetation cover and soil, which should be taken into account during investment. For example, geobotanical maps are used to calculate losses to indigenous peoples, whose lands are temporarily withdrawal during the implementation of an industrial subsoil use project.

- Selection of investment projects according to their priority. Here the following question must be resolved: what criterion will be used in the basis of priority? What is the purpose of its implementation? On the one hand, it is important for the investor to make a profit, on the other, it is important for the regional government to ensure a decent standard of living for the local population. In Russia, approaches have been developed for ranking and selecting projects that could take into account the interests of both [10].

- Development of the icebreaker fleet, transport based on safe innovations, as well as the introduction of green technologies in construction and facilities providing subsoil use. The implementation of the principles of a green economy will help preserve the fragile and sensitive nature of the Arctic [11].

These tasks cannot be solved without government assistance and incentives. It is necessary to develop mechanisms of administrative and financial support, among which the special tax regimes and public-private partnerships should be highlighted.

\section{Acknowledgement}

The paper is prepared by the financial support of RFBR project 21-510-22001.

\section{References}

1. F. Hill, F. Fee Demokratizatsiya, 10 (4), 462487 (2002)

2. Novak announced the construction of more than ten LNG plants in Russia, retrived from: https://www.rbc.ru/business/29/01/2021/6013dc 059a79473d601ea315
3. Decree of the President of the Russian Federation of N 645Strategy for the development of the Arctic zone of the Russian Federation and ensuring national security for the period up to 2035 (2020) retrieved from: http://www.kremlin.ru/acts/news/64274

4. Moe, O. S. Stokke, Arctic Review on Law and Politics, 10, 24-52 (2019) http://dx.doi.org/10.23865/arctic.v10.1374

5. Publication calendar of official statistical information on the socio-economic development of the Arctic zone of the Russian Federation in 2020, retrieved from: https://gks.ru/free doc/new_site/region_stat/cal endarl-2020.htm

6. V.I. Denisov, V.N. Chernogradskii, I.M. Potravny, P.Y. Ivanova, Studies on Russian Economic Development, 31(4), 404-410 (2020)

7. Government of Nunavut Iqaluit International Airport Improvement Project 2014 Retrieved from:

https://gov.nu.ca/sites/default/files/iqaluit_inter national_airport_improvement_project_report.p $\underline{\mathrm{df}}$

8. $\overline{\mathrm{V}}$. Gassiy, V. Stoikov, E3S Web of Conferences, 177, 04005 (2020)

9. K. Mohn, The Energy Journal, 40 (3) 199-226 (2019) http://dx.doi.org/10.5547/01956574.40.3.kmoh

10. Novoselov, I. Potravny, I. Novoselova, V. Gassiy, Polar Sci., 14, 68-77 (2017)

11. Kyriaki Noussia, European Energy and Environmental Law Review, 3, 98-109 (2020) 